\title{
The Fourth Amendment and Facilities Inspections Under the Chemical Weapons Convention
}

\author{
Robert F. Greenlee $\dagger$
}

The Supreme Court has never declared unconstitutional a treaty that has been ratified by the Senate. ${ }^{1}$ However, a recent treaty may push the Court's general reluctance to interfere with international politics to the limit. Few treaties have contained as many potential constitutional pitfalls as the Chemical Weapons Convention ("CWC" or "Convention"), ${ }^{2}$ which attempts to control the production of and ultimately to eradicate chemical weapons.

The CWC requires that all signatory states, "State Parties," submit to complex and highly intrusive procedures to verify their compliance with the treaty. These procedures include on-site inspections of public and private facilities conducted by an international verification team. Because chemical weapons are manufactured in both public and private facilities, many inspections in the United States will occur in privately owned facilities-raising Fourth Amendment concerns. The Fourth Amendment protects such private facilities from unreasonable government searches. ${ }^{3}$ Although the CWC attempts to address constitutional concerns of State Parties, ${ }^{4}$ it does not possess a warrant requirement. The absence of a warrant requirement is problematic because, under Fourth Amendment jurisprudence, warrantless searches are pre-

$\dagger$ B.A. 1996, Yale University; J.D. Candidate 1999, The University of Chicago.

1 Louis Henkin, Foreign Affairs and the Constitution 137 (Norton 1972). However, at least one lower court has held portions of a treaty to be unconstitutional. See id at $\mathbf{3 8 3}$ n 34.

2 Convention on the Prohibition of the Development, Production, Stockpiling and Use of Chemical Weapons and on their Destruction, Senate Treaty Doc 103-21, 103d Cong, 1st Sess 278 (1993). The treaty was ratified on April 24, 1997. Resolution of Ratification for the Chemical Weapons Convention ("Ratification Resolution"), 105th Cong, 1st Sess, in 143 Cong Rec S 3651 (Apr 24, 1997).

The Fourth Amendment provides, "The right of the people to be secure in their persons, houses, papers, and effects, against unreasonable searches and seizures, shall not be violated, and no Warrants shall issue, but upon probable cause, supported by Oath or affirmation, and particularly describing the place to be searched, and the persons or things to be seized." US Const, Amend IV.

4 The CWC requires that access for inspection remain subject to "any constitutional obligations ... with regard to proprietary rights or searches and seizures." CWC, Annex on Implementation and Verification ("Verification Annex"), Part X, I 41, S Treaty Doc 103-21 at 435 . 
sumptively unreasonable and therefore presumptively unconstitutional. ${ }^{5}$

Significant interests are at stake in this debate. On the one hand is the desire to eliminate all chemical weapons, which are particularly frightening because of their use in terrorist attacks ${ }^{6}$ and genocide, ? as well as in conventional warfare. For inspections to be effective, ${ }^{8}$ governments must be prevented from impeding the work of verification inspectors. This is especially true as verification schemes are increasingly being relied upon as the means to enforce international treaties. ${ }^{9}$ Furthermore, it is important for the United States to abide by its international commitments; if the United States breaches the CWC, other countries are likely to follow suit. On the other hand, international law, and the American implementation thereof, must respect an individual's right to be free from unreasonable searches and seizures. This right is particularly important in the context of the CWC because of the possibility that members of an inspection teams may disclose or steal confidential business information. ${ }^{10}$

In light of these constitutional concerns, the Senate imposed a number of conditions when it ratified the CWC; one condition was a requirement that warrants be obtained for all nonconsensual inspections. ${ }^{11}$ However, the Senate may not be empowered to condition the treaty responsibilities of the United States in this fashion. Some commentators have suggested that

- See Camara v Municipal Court, 387 US 523, 528-29 (1967) (noting that a "search of private property without proper consent is 'unreasonable' unless it has been authorized by a valid search warrant").

${ }^{\circ}$ Consider, for example, the 1995 attack on a Tokyo subway train by the Aum Shinrikyo. This risk is increased by the massive availability of Russian chemical weapons supplied to Russian organized crime. See Jo Durden-Smith, Russian Mafia Moves West, Moscow Times (Mar 25, 1997) (noting the connection between Aum Shinrikyo and Russian chemical weapons experts).

7 Recall the use of chemical weapons by the Iraqi government on its Kurdish minority population. See Lara Marlowe, Kurds Believe Only the U.S. Can Save Them, San Fran Chron A12 (June 18, 1991) (alleging that "[t]he Iraqis used chemical weapons to depopulate" Kurdish regions).

8 Effectiveness of the verification procedures will depend on the global perception that states cannot mask noncompliance with CWC obligations.

- For example, efforts continue to negotiate amendments to the Biological Weapons Convention to include a verification regime similar to the CWCs. See Barry Kellman, Bridling the International Trade of Catastrophic Weaponry, 43 Am U L Rev 755, 817-19 (1994).

${ }^{10}$ Aware of the potential for theft of confidential business information, the CWC includes an annex that sets out broad measures to deter theft. See CWC, Annex on the Protection of Confidential Information ("Confidentiality Index"), S Treaty Doc 103-21 at 445.

"However, regular on-site inspections must meet the standard for administrative searches, while challenge inspections are required to meet the more rigorous criminal standard. Ratification Resolution § 2(28)(a)(i)-(ii), 143 Cong Rec at S 3657. 
such warrantless inspections are constitutional under the Fourth Amendment exceptions for administrative searches of closely regulated industries ${ }^{12}$ and national security interests. ${ }^{13}$ Others have considered whether courts should decline to decide these questions because the issues raised are political questions of foreign relations, expressly delegated to the executive branch. ${ }^{14}$ No solution, however, has yet been proposed that protects both the need to verify compliance with the CWC and the need to ensure civil liberties.

This Comment concludes that an expanded national security exception to the Fourth Amendment reasonableness requirement provides the optimal solution to the constitutional problems inherent in CWC inspections. Part I analyzes the CWC, focusing on the structure of the verification procedures. Part II considers the requirements of the Fourth Amendment and analyzes the potential effects of the CWC in action. Part III considers four potential solutions to the problem, including expanding the national security exception. Part IV analyzes the potential ramifications of expanding the national security exception to include the verification of disarmament procedures.

\section{ThE ChEMICAL WEAPONS CONVENTION}

The negotiations that produced the Chemical Weapons Convention began in 1970 and were concluded in Paris on January 13, 1993 with the signatures of sixty-five member states. ${ }^{15}$ The

${ }^{12}$ See David G. Gray, Note, "Then the Dogs Died": The Fourth Amendment and Verification of the Chemical Weapons Convention, 94 Colum L Rev 567, 644-50 (1994) (advocating a modified version of the closely regulated industry exception).

${ }^{13}$ See Debbie Ryan Bing-Zaremba, Comment, Knock, Knock, Who's There?: Can Chemical Weapons Inspectors Enter U.S. Facilities Without a Search Warrant?, 11 Temple Intl \& Comp L J 57, 75 (1997) (arguing that "the government's strong interest in protecting its national security" would suffice in countering Fourth Amendment challenges). See also Thomas A. Connolly, Note, Warrantless On-Site Inspections for Arms Control Verification: Are They Constitutional?, 24 Stan J Intl L 179, 222 (1987) (arguing that "isolated Presidential authorizations to inspect," in the exercise of national security power, may be permissible).

"See Edward A. Tanzman, Constitutionality of Warrantless On-Site Arms Control Inspections in the United States, 13 Yale J Intl L 21, 41 (1988) (arguing that "a violation of private rights," as distinguished from a "dispute between coequal branches of government," might be justiciable). See also Kevin C. Kennedy, The Constitution and On-Site Inspection, 14 Brooklyn J Intl L 1, 3 (1988) (noting concern that permitting foreign delegations to conduct searches may constitute an unconstitutional delegation of governmental authority).

${ }^{16}$ See Patrick McDowell, Countries Sign Historic Treaty Banning Chemical Weapons, AP (Jan 13, 1993). Through February 1998, 168 nations had signed the CWC and 106 of these countries had ratified it. See Ray Moseley, Agency Oversees End of Chemical Weapons Era in Many Nations, Chi Trib 13 (Feb 10, 1998). 
CWC was intended to extend the principles and objectives of the Geneva Protocol of $1925^{16}$ and the Convention on the Prohibition of the Development, Production and Stockpiling of Bacteriological (Biological) and Toxic Weapons and on their Destruction. ${ }^{17}$ The CWC's express purpose is "to exclude completely the possibility of the use of chemical weapons"18 through the destruction of all stocks of chemical weapons and through the implementation of a verification scheme designed to ensure that new weapons are not produced.

Each State Party, upon ratifying the CWC, assumes five responsibilities. First, the State Party must declare the existence of all chemical weapons and chemical weapons production facilities and then destroy them. ${ }^{19}$ Second, the State Party must cease future production and stockpiling of chemical weapons. ${ }^{20}$ Third, the State Party must provide a general plan for the destruction of chemical weapons, ${ }^{21}$ declare its annual progress on the implementation of the destruction process, ${ }^{22}$ and declare and provide information about the facilities that currently produce restricted chemicals for non-prohibited uses. ${ }^{23}$ Fourth, the State Party must agree to allow its declarations to be verified by inspection. ${ }^{24}$ The verification regime has two main components: regular, on-site inspections of declared facilities, and challenge inspections, which allow a State Party to request the inspection of any facility of another State Party. ${ }^{25}$ Fifth, each State Party must pass domestic legislation implementing the CWC. ${ }^{26}$ To implement the CWC, each State Party must create a National Authority to assist in verification measures ${ }^{27}$ and must make criminal all activities prohibited by the CWC. ${ }^{28}$

In order to ensure compliance with its terms, the CWC authorizes the creation of the Organization for the Prohibition of

${ }^{16}$ Prohibition of the Use in War of Asphyxiating, Poisonous or Other Gases, and of Bacteriological Methods of Warfare, 26 UST 571, TIAS No 8061 (1925).

${ }^{17} 26$ UST 583, TIAS No 8062 (1972).

${ }^{18} \mathrm{CWC}$, Preamble, $S$ Treaty Doc 103-21 at 279.

10 Id at Art I, III 2-4, S Treaty Doc 103-21 at 281.

${ }^{20}$ Id at Art I, I 1(a), S Treaty Doc 103-21 at 281.

${ }^{21}$ Id at Verification Annex, Part IV (A), II 6, S Treaty Doc 103-21 at 363.

${ }^{22}$ Id at Art IV, II 7(b), S Treaty Doc 103-21 at 290 (governing annual progress reports).

${ }^{23}$ Id at Art III, II 1(c), S Treaty Doc 103-21 at 287-88.

24 Id at Art IV, II 5 (relating to weapons), S Treaty Doc 103-21; id at Art V, II 7(b), S Treaty Doc 103-21 at 292 (relating to facilities). See also id at Verification Annex, $S$ Treaty 103-21 at 332-444 (detailing verification procedures).

${ }^{25}$ Id at Art IX, II 8-25, S Treaty Doc 103-21 at 311-13 (discussing challenge inspections).

${ }^{26}$ Id at Art VII, S Treaty Doc 103-21 at 297-98.

27 Id at Art VII, II 4, S Treaty Doc 103-21 at 297-98.

${ }^{28}$ Id at Art VII, I 1(a), S Treaty Doc 103-21 at 297-98. 
Chemical Weapons ("OPCW"). ${ }^{29}$ The OPCW is composed of three distinct bodies: the Conference of States Parties (the "Conference"), the Executive Council, and the Technical Secretariat. ${ }^{30}$

The Conference, composed of one representative from each State Party, maintains primary authority over the OPCW. ${ }^{31}$ The Executive Council is a group of forty-one members elected by the Conference for the purpose of facilitating the effective discharge of CWC responsibilities. ${ }^{32}$ The Technical Secretariat is the enforcement arm of the OPCW, responsible for managing its day-today operations. ${ }^{33}$

\section{A. The Verification Process}

The CWC verification system has three major elements: mandatory information declarations, periodic on-site inspections of declared facilities, and challenge inspections. ${ }^{34}$ The verification process is designed to control the creation of chemical weapons by limiting the synthesis of toxic chemicals ${ }^{35}$ and by regulating the

20 Id at Art VIII, I 1, S Treaty Doc 103-21 at 299.

30 Id at Art VIII, I 4, S Treaty Doc 103-21 at 299.

s1 Id at Art VIII, I 19, S Treaty Doc 103-21 at 301 ("The Conference shall be the principal organ of the organization."); id at Art VIII, I 9, S Treaty Doc 103-21 at 300 ("Each member shall have one representative in the conference."). The Conference determines the scope of authority of the Executive Council and the Technical Secretariat, votes upon matters brought to its attention by the Executive Council, and takes "the necessary measures to ensure compliance with [the CWC]." Id at Art VIII, II 21(k), S Treaty Doc 103-21 at 302. For responsibilities of the Conference, see id at Art VIII, III 19-22, S Treaty Doc 103-21 at 301-02.

32 The delegates are nominated with emphasis on "the importance of chemical industry," "political and security interests," and "equitable geographic distribution." Id at Art VIII, I 23, S Treaty Doc 103-21 at 303. The Executive Council is an oversight group that supervises the Technical Secretariat. It has the power to stop frivolous challenge inspections. In addition, it must approve all agreements (including facility agreements) relating to verification of the CWC. Id at Art VIII, III 31, 34, S Treaty Doc 103-21 at 304-05; id at Art IX, I 17, S Treaty Doc 103-21 at 312 (relating to challenge inspections). Facility agreements are general agreements as to the scope and nature of an allowable inspection.

${ }^{33}$ Id at Art VIII, II 37-38, S Treaty Doc 103-21 at 306. It performs verification inspections and data analysis. The Secretariat is composed of as many inspectors and other professionals as are necessary to effectively implement the CWC. Id. The Director General of the Technical Secretariat will hire employees of the Secretariat according to need. Id at Art VIII, II 43-44, S Treaty Doc 103-21 at 307. Inspectors are chosen from a list submitted by each State Party and tend to be highly skilled professionals. See Moseley, Agency Oversees, Chi Trib at 13 (cited in note 15).

* The verification process is detailed in the Verification Annex of the CWC. The Annexes of the CWC are subject to amendment or to reservations, which adhere to the objects and purposes of the Convention. See CWC, Art XV, S Treaty Doc 103-21 at 320-21 (permitting amendments); id at Art XXII, S Treaty Doc 103-21 at 323 (proscribing reservations to the Annexes that are "incompatible with [the Convention's] object and purposen).

${ }^{36}$ Toxic chemicals are defined as "[a]ny chemical which through its chemical action on life processes can cause death, temporary incapacitation or permanent harm to humans or 
production of "precursors," which are the components necessary to synthesize toxic chemicals. ${ }^{36}$ Chemicals are classified according to their risk and are divided into four categories: Schedule 1, Schedule 2, Schedule 3, and Other. ${ }^{37}$

The foundation of the verification regime is mandatory information disclosure. Each State Party is required to list all active facilities that produce regulated chemicals, to report the amounts of these chemicals produced, and, in some instances, to allow continuous monitoring of production by on-site data collection instruments. ${ }^{38}$ Based on the declared data, the Technical Secretariat performs verification inspections. In addition, data declaration serves as a baseline against which information discovered during a challenge inspection is measured; any unregulated, undeclared production of toxic chemicals discovered by a challenge inspection is evidence of noncompliance with the CWC.

Based on the data declared by State Parties, the Technical Secretariat performs regular on-site inspections to verify that declared facilities are producing declared chemicals at declared levels. Each declared facility is subject to an initial on-site inspection to verify the initial data, ${ }^{39}$ as well as subsequent inspections, the style and frequency of which are to be determined by the Schedule and amount of chemicals produced.

Schedule 1 on-site inspections will be conducted at least once a year, ${ }^{40}$ subject to the terms of the facility agreement made between the facility owner and the Executive Council. ${ }^{41}$ The regular

animals." Id at Art II, I 2, S Treaty Doc 103-21 at 282.

${ }^{36}$ Id at Art II, II 3, S Treaty Doc 103-21 at 282.

${ }^{37}$ Id at Annex on Chemicals, Part A, S Treaty Doc 103-21 at 326-27. Schedule 1 chemicals are the most toxic or dangerous; they have few uses other than as chemical weapons and have previously been used as a chemical weapon. Schedule 1 chemicals may only be produced at one facility per state, at a quantity of 1 tonne per year, and are subject to continuous monitoring by the Technical Secretariat. Schedule 2 chemicals are dangerous chemicals or precursors that are not generally mass-produced. Schedule 2 chemicals are subject to production limitations that vary by the individual chemical. Schedule 3 chemicals are toxic chemicals that can be used as chemical weapons or precursors to chemical weapons, but which are extensively produced for non-prohibited activities as well. "Other" chemicals include all organic chemicals, except petroleum products and other combustibles that have a certain chemical composition. See id at Verification Annex, Part IX, II 1, S Treaty Doc 103-21 at 423.

${ }_{38}$ Id at Art VI, III 2-8, S Treaty Doc 103-21 at 295-96. The CWC requires an initial declaration, which will be verified by inspections, followed by annual declarations, which are subject to further verification by inspection. See id at Verification Annex, S Treaty Doc 103-21 at 332-444.

39 Id at Verification Annex, Part III(A), S Treaty Doc 103-21 at 357-58.

to "The number, intensity, duration, timing, and mode of inspections for a particular facility shall be based on the risk to the object and purpose of this Convention posed by the relevant chemicals." Id at Verification Annex, Part VI, II 23, S Treaty Doc 103-21 at 407.

${ }^{11}$ Id at Part VI, II 25, S Treaty Doc 103-21 at 407 (giving State Parties 180 days to 
inspection of Schedule 1 facilities will determine the accuracy of annual data declarations. ${ }^{42}$ The inspection will be conducted by inspectors of the Technical Secretariat, who must strictly abide by the facility agreement and who must ensure that the inspection imposes the "least possible inconvenience."

Schedule 2 facilities, like Schedule 1 facilities, are subject to yearly on-site inspections; these inspections are also to occur in accordance with facility agreements made between the facility owner and the Executive Council. ${ }^{44}$ Again, Schedule 2 inspections must impose no more than minimal intrusion. In actual practice, an inspection of a Schedule 2 facility will be similar to the inspection of a Schedule 1 facility. However, inspection teams must provide forty-eight hours notice before inspections. ${ }^{45}$

Inspections of Schedule 3 and Other facilities, which are similar enough in practice to be considered together, will be conducted on a random basis. Due to the large number of these facilities, ${ }^{46}$ the CWC limits the number that may be searched. The total number of inspections of Schedule 3 and Other facilities combined may not exceed twenty per year, excluding challenge inspections. ${ }^{47}$ There is no CWC requirement that facility agreements be reached for these inspections. ${ }^{48}$ The inspection teams, however, are limited by the scope of their inspection mandates and by the general rule that they must minimize interference with operations. The Technical Secretariat must serve notice to the inspected state within 120 hours (or five days) of arrival at the point of entry. ${ }^{49}$

The challenge inspection procedure differs substantially from the procedure required for regular inspections. A State Party may be subject to an unlimited number of challenge inspections per year. Both declared and undeclared facilities are subject to chal-

conclude facility agreements).

42 Id at Verification Annex, Part VI, I 21, S Treaty Doc 103-21 at 407.

${ }^{43}$ Id at Verification Annex, Part II, II 40, S Treaty Doc 103-21 at 351.

" Id at Verification Annex, Part VII, II 24, S Treaty Doc 103-21 at 414.

45 Id at Verification Annex, Part VII, I 30, S Treaty Doc 103-21 at 415 (mandating forty-eight hours notice before arriving at the site, not at the point of entry).

46 There may be as many as one thousand Schedule 3 facilities and ten thousand Other facilities in the United States alone. See Office of Technology Assessment ("OTA"), The Chemical Weapons Convention: Effects on the U.S. Chemical Industry 15 (GPO 1993).

${ }^{17}$ CWC, Verification Annex, Part VIII, II 16, S Treaty Doc 103-21 at 420 (Schedule 3 facilities); id at Verification Annex, Part IX, II 13, S Treaty Doc 103-21 at 420 (Other facilities).

48 Id at Verification Annex, Part VII, I 19, S Treaty Doc 103-21 at 420 ("There shall be no facility agreement, unless requested by the inspected State Party.").

19 Id at Verification Annex, Part VIII, II 25, S Treaty Doc 103-21 at 421 (Schedule 3 facilities); id at Verification Annex, Part IX, II 21, S Treaty Doc 103-21 at 426 (Other facilities). 
lenge inspections. ${ }^{50}$ Challenge inspections occur with minimal notice. Only twelve hours notice is required before arrival at the point of entry, ${ }^{51}$ and inspections are designed to begin within twelve hours after arrival in the target State. ${ }^{52}$ Challenge inspections are also intrusive; the inspectors will closely monitor egress and ingress to the inspected facility, and the inspection mandate allows greater intrusion than during other inspections. ${ }^{53}$

\section{B. Conditions Added at Ratification}

Although Article XXII of the CWC prohibits State Parties from adding reservations to its Articles, ${ }^{54}$ the United States Senate ratified the CWC subject to twenty-eight conditions. ${ }^{55}$ One of these conditions asserted a congressional right to make reservations notwithstanding Article XXII. ${ }^{56}$. While it is unclear how the legal conundrum generated by these conditions will be resolved, one particular condition merits immediate discussion.

The Senate's Condition 28 to the CWC requires that the United States National Authority, the executive agency responsible for oversight of CWC activities, seek a warrant for any inspections, routine or challenge, conducted on American territory. ${ }^{57}$

${ }^{\circ 0}$ Technically, challenge inspections are limited because a challenge inspection will not be approved without the presentation of some evidence that tends to demonstrate reasonableness. See id at Art IX, I 9, S Treaty Doc 103-21 at 311. However, veto of a proposed challenge inspection requires a three-quarters majority vote of the Executive Council, which suggests that authority for challenge inspections will be freely given. Id at Art IX, II 17, S Treaty Doc 103-21 at 312.

s1 Id at Verification Annex, Part X, I 6, S Treaty Doc 103-21 at 429.

${ }_{22}$ Id at Verification Annex, Part X, II 23, S Treaty Doc 103-21 at 432.

${ }^{s 3}$ The Verification Annex contains detailed instructions regarding the perimeter to be inspected. Unlike regular inspections, where only limited (often prearranged) areas may be inspected, challenge inspections are required to inspect the entire perimeter, subject only to confidentiality concerns. See id at Verification Annex, Part X, 11 42-52, S Treaty Doc 103-21 at 435-37.

${ }^{34}$ Id at Art XXII, S Treaty Doc 103-21 at 323 ("The Articles of this Convention shall not be subject to reservations. The Annexes of this Convention shall not be subject to reservations incompatible with its object and purpose.").

${ }^{s 5}$ Part III.A discusses whether Congress actually has the power to ratify a treaty conditionally.

ss "[T]he President shall certify to the Congress that the United States has informed all other States Parties to the Convention that the Senate reserves the right, pursuant to the Constitution of the United States, to give its advice and consent to ratification of the Convention subject to reservations, notwithstanding Article XXII of the Convention." Ratification Resolution § 2(1), $143 \mathrm{Cong}$ Rec at $S 3651$. See also id at § 2(17), 143 Cong Rec at $S 3656$ (discussing the Senate's constitutional prerogative).

${ }^{52}$ See Ratification Resolution § 2(28), 143 Cong Rec at S 3657. See also note 11. The bill proposed to implement the CWC exhaustively details the information that must be provided to obtain a warrant of each type. See Chemical Weapons Convention Implementation Act of 1997 \& 406(a) ("Implementation Bill"), S 610, 105th Cong, 1st Sess (Apr 17, 1997), in 143 Cong Rec S 3355, S 3358 (Apr 17, 1997) (detailing requirements for Lead 
This condition will likely be buttressed by the legislation to implement the CWC that is currently pending in the Senate. ${ }^{58}$ The implementing legislation requires National Authority involvement in every inspection conducted on United States territory ${ }^{59}$

If constitutional, the Senate's conditions will overcome the CWC's Fourth Amendment problems. However, as will be discussed below, there is good reason to think that the Senate may not create these conditions constitutionally.

\section{FOURTH AMENDMENT JURISPRUDENCE}

The effectiveness of the verification regime outlined above will determine the overall success of the CWC. This regime, however, does not require warrants or provide other procedural safeguards that would ensure the reasonableness of an inspection. ${ }^{60}$ Without some assurance of reasonableness, inspections made pursuant to the CWC may violate the Fourth Amendment.

The Fourth Amendment protects United States residents ${ }^{61}$ from unreasonable searches and seizures by their government. But constitutional protection exists only to the extent that the United States exercises jurisdiction. Courts have not traditionally afforded Fourth Amendment protection to United States citizens who are searched by agents of foreign governments, unless the United States government has participated in the search in a significant way. ${ }^{62}$ This Comment will focus on searches of pri-

Agency affidavit necessary for the issuance of a warrant to inspect).

st As of May 6,1998, the Implementation Bill was under review in the Senate Foreign Relations Committee.

so Chemical Weapons Convention Implementation Act of 1997, as amended, ("*Revised Implementation Bill") $\S 303(b)(2)$, S 610, 105th Cong, 1st Sess, in 143 Cong Rec S 5070, 5074 (May 23, 1997) (requiring National Authority to coordinate the designation of federal employees to accompany inspectors). Mandatory inclusion of the National Authority will likely also resolve any potential problems involving a violation of Article II, $\S 2$ of the Constitution. See Part III.A.

${ }^{\infty}$ The CWC does require that challenge inspections must meet the constitutional standards of the inspected State Party. See note 4. However, because of fears that rogue states will use the U.S.-created loophole to protect their chemical arsenals, the United States should not rest to heavily on this pillar, lest the effectiveness of the entire CWC topple. See Part IV.C.1.

"11 Fourth Amendment protection is limited to "the people" of the United States. US Const, Amend IV. Traditionally, this term has been applied to resident aliens as well as citizens. INS $v$ Lopez-Mendoza, 468 US 1032, 1042 (1984) (analyzing the applicability of the exclusionary rule to evidence obtained after an arrest that violated aliens' Fourth Amendment rights). See also Kwang Hei Chew v Colding, 344 US 590, 596 (1953) (noting that "it is well established that" resident aliens enjoy Fifth Amendment protection).

2 See Lustig $v$ United States, 338 US 74, 79 (1949) ("The decisive factor in determining" whether the Fourth Amendment has been violated "is the actuality of a share by a federal official in the total enterprise."); Stonehill $v$ United States, 405 F2d 738, 743 (9th Cir 1968) (" $[T]$ he Fourth Amendment could apply . . . only if Federal agents so substan- 
vately owned facilities on American soil, which is where the Fourth Amendment difficulties will primarily occur. ${ }^{63}$

\section{A. Fourth Amendment Thresholds}

The threshold determination for any Fourth Amendment question is whether there is sufficient governmental action to trigger Fourth Amendment protection. In the context of the CWC, the question is whether a search of a privately owned facility conducted by an OPCW inspection team constitutes sufficient governmental action to be considered a "joint venture." If the search does not constitute a joint venture, then it will not be considered a governmental search, and the Fourth Amendment will not apply. While the law on joint ventures abroad is well settled, ${ }^{65}$ courts have not yet determined whether a domestic search by an international organization can constitute a joint venture.

Most searches will clearly meet the joint venture standard of "significant participation" when the National Authority accompanies an inspection. ${ }^{66}$ Then the search will be considered a joint

tially participated in the raids so as to convert them into joint ventures between the United States and the foreign officials.").

${ }^{*}$ A related question is whether courts will hold that searches conducted abroad by the OPCW of facilities owned by United States citizens have enough participation by the government to create Fourth Amendment concerns. In these situations, courts must determine whether the United States has contributed enough aid to meet the significant participation standard discussed in Part II.A. Any situation where the United States significantly participates-a question of fact that depends on each search's facts and circumstances-raises the same constitutional concerns as domestic searches of private facilities.

et Generally, searches by private citizens that do not involve an agent of the federal government do not violate the Constitution. See Burdeau v McDowell, 256 US 465, 475 (1921) ("It is manifest that there was no invasion of the security afforded by the Fourth Amendment . . . as whatever wrong was done was the act of individuals in taking the property of another."). The test for whether a search has sufficient governmental involvement to constitute a joint venture is based upon "participation" and thus is a question of fact. Moody v United States, 163 A2d 337, 340 (DC Mun Ct App 1960), citing Lustig, 338 US at 78 (" $[A]$ search is a search by a federal official if he had a hand in it.").

${ }^{66}$ In an international context, the general rule is that searches performed by a sovereign government in its own territory to enforce United States law are not limited by the Fourth Amendment, but searches with United States participation are subject to the same "significant participation" test as a joint venture occurring on United States soil would be. United States $v$ Hawkins, 661 F2d 436, 455-56 (5th Cir 1981) (noting that Fourth Amendment protections apply to foreign government's action "if the foreign authorities were acting as agents for their American counterparts"). But see Brulay v United States, 383 F2d 345, 348 (9th Cir 1967) (stating that the prophylactic purposes of the exclusionary rule are inapplicable to foreign governments). This seems inapplicable in the domestic context, since the United States is not conducting the search. For commentary noting the unsettled nature of the law on domestic searches by nongovernment parties, see David A. Koplow, Arms Control Inspection: Constitutional Restrictions on Treaty Verification in the United States, 63 NYU L Rev 229, 295-96 (noting that, in situations such as an international inspection on American territory, the law is unresolved).

${ }^{63}$ This is precisely the solution offered by pending legislation. See Revised Implemen- 
venture. Significant participation may also include government facilitation of a search, which the United States is obligated to provide under the CWC. ${ }^{67}$ Under the "significant participation" standard for joint ventures, ${ }^{68}$ the government need not actually conduct the search itself.

On the other hand, it is not immediately apparent whether inspections that are not supervised by the United States government meet the "significant participation" standard. However, Article II, Section 3 of the United States Constitution requires that the President "take Care that the Laws [of the United States] be faithfully executed." The OPCW is not a part of the executive branch, ${ }^{69}$ but searches carried out by the OPCW will enforce a federal statute. ${ }^{70}$ Conferring executive authority will necessarily add some degree of governmental involvement, raising the inspection to a Fourth Amendment-protected joint venture. Therefore, any inspection conducted by an international inspection team, with or without actual United States government involvement in the inspection itself, will likely be a governmental search and therefore will implicate the Fourth Amendment.

Even if a CWC inspection involves governmental action, it does not implicate the Fourth Amendment unless the inspection qualifies as a "search" within the meaning of the Fourth Amendment: "[T]here is a twofold requirement, first that a person [searched] have exhibited an actual (subjective) expectation of privacy and, second, that the expectation be one that society is prepared to recognize as 'reasonable." ${ }^{\text {'m1 }}$ Businesses, not just indi-

tation Bill § 303(b)(2), 143 Cong Rec at S 5074.

"The CWC requires that inspected State Parties provide transportation, lodging, and food to inspectors. CWC, Verification Annex, Part II, II 26, S Treaty Doc 103-21 at 349. This activity clearly facilitates CWC inspections.

- See Elkins $v$ United States, 364 US 206, 223 (1960) ("[E]vidence obtained by state officers during a search which, if conducted by federal officers, would have violated the defendant's immunity from unreasonable searches and seizures under the Fourth Amendment is inadmissible."); Lustig, 338 US at 78-79 (holding that a federal agent, called in by police after the search was performed, "had a hand in" the search and therefore the search deserved Fourth Amendment protection); Stonehill, 405 F2d at 743 (Search conducted by foreign officials only raises Fourth Amendment questions if accompanied by United States participation so significant as to convert the raid into a joint venture.); Corngold $v$ United States, 367 F2d 1, 5 (9th Cir 1966) (Search conducted jointly by air carrier and customs officers constitutes a joint venture.).

* See Buckley $v$ Valeo, 424 US 1, 126 (1976) (Executive officers must be appointed pursuant to Article II, $\S 2$.). See also Kennedy, 14 Brooklyn J Intl L at 20-24 (cited in note 14) (discussing Article II concerns).

${ }^{70}$ Specifically, the OPCW will enforce the implementation legislation, which makes violations of the CWC criminal. See Revised Implementation Bill § 201, 143 Cong Rec at S 5072-74.

" Katz v United States, 389 US 347, 361 (1967) (Harlan concurring). 
viduals, may possess reasonable expectations of privacy that are protected by the Fourth Amendment. ${ }^{72}$ A search of a person who meets these criteria will be unconstitutional unless the search was reasonable. A warrant is the principal method of meeting this reasonableness requirement.

\section{B. The Warrant Requirement}

The government is presumptively required to obtain a warrant to establish the constitutionality of a search. ${ }^{73}$ Warrants are required for administrative and criminal searches ${ }^{74}$ of both homes and businesses. ${ }^{75}$ The warrant requirement exists for two reasons. First, the warrant requirement assures "that the deliberate, impartial judgment of a judicial officer will be interposed between the citizen and the police. .76

Second, the warrant requirement protects citizens from oppressive interference and intrusions from agents of the government. ${ }^{77}$ To ensure a reasonable right to privacy, a warrant will be granted only on the basis of probable cause. ${ }^{78}$ To establish probable cause, the government must present sufficient evidence to demonstrate that the proposed search is reasonable. ${ }^{79}$ The particular contours of probable cause vary by situation. ${ }^{80}$

${ }^{72}$ See $v$ City of Seattle, 387 US 541, 543 (1967).

${ }^{73}$ See Camara $v$ Municipal Court, 387 US 523, 528-29 (1967) (“[O]ne governing principle ... has consistently been followed: except in certain carefully defined classes of cases, a search of private property without proper consent is 'unreasonable' unless it has been authorized by a valid search warrant."). But see Terry $v$ Ohio, 392 US 1, 27 (1968) (holding that a warrant is unnecessary where circumstances create reasonable belief of danger and preclude obtaining judicial approval).

"See Camara, 387 US at 534. Although the standards for criminal and administrative warrants vary, administrative warrants generally require a lesser standard of evidence than do criminal warrants.

${ }^{75}$ Payton $v$ New York, 445 US 573, 586 (1979) (homes); See, 387 US at 543 (businesses).

${ }^{78}$ Wong Sun v United States, 371 US 471, 481-82 (1963).

${ }^{n}$ Berger $v$ New York, 388 US 41, 53 (1967) (stating that the purpose of the Fourth Amendment is "to safeguard the privacy and security of individuals against arbitrary invasions by governmental officials").

${ }^{78}$ Shadwick $v$ City of Tampa, 407 US 345, 350 (1972).

${ }^{70}$ See Camara, 387 US at 534-35 (distinguishing the level of evidence required for criminal and administrative warrants).

${ }^{80}$ Generally, the level of protection offered by the Fourth Amendment depends upon the subjective expectation of privacy. Katz, 389 US at 361-62 (Harlan concurring). The warrant requirements for administrative searches are less extensive than for criminal warrants, Camara, 387 US at 534-35 (noting government interest in preventing unintentional code violations), and the amount of evidence necessary to obtain a warrant may be tailored according to the governmental interest involved. See Skinner $v$ Railway Labor Executives Association, 489 US 602, 619 (1989) (balancing "governmental and privacy interests"). 
Although warrants are generally required for a search to qualify as reasonable, there are a few exceptions to the warrant requirement. These exceptions apply to situations involving emergency, ${ }^{81}$ hot pursuit, ${ }^{82}$ health risks, ${ }^{83}$ searches of closely regulated industries, ${ }^{84}$ and the national security exception. ${ }^{85}$ The two exceptions that pertain directly to the question of warrantless CWC inspections are the closely regulated industries exception and the national security exception.

\section{The Closely Regulated Industry Exception}

Courts have established a general exception to the warrant requirement for administrative searches of industries subject to close regulation. ${ }^{86}$ Though the justification for the exception has shifted throughout its history, ${ }^{87}$ the exception depends upon implicit acceptance of the test formulated in Katz $v$ United States. ${ }^{88}$ In Katz, the Supreme Court limited the applicability of a Fourth Amendment search to those situations in which the individual searched had both a subjectively and objectively reasonable expectation of privacy. ${ }^{89}$ Participation in a closely regulated industry subjects an individual to such pervasive and regular scrutiny that one cannot maintain either an objective or a subjective expectation that the regulated premises will be private. Therefore, an inspection of such premises does not constitute a "search" within the meaning of the Fourth Amendment. Because this ex-

${ }^{31}$ See United States $v$ Rubin, 474 F2d 262, 268 (3d Cir 1973) ("The emergency circumstances exception is "established."').

22 See Warden, Maryland Penitentiary v Hayden, 387 US 294, 298-99 (1967) (allowing warrantless search by police in pursuit of robbery suspect).

* See Camara, 387 US at 539 (discussing health emergency situations where warrantless searches might be permissible).

* See, for example, Donovan $v$ Dewey, 452 US 594, 600-05 (1981).

${ }^{25}$ See United States $v$ Erlichman, 546 F2d 910, 924-26 (DC Cir 1976).

*6 Controversy concerning administrative searches arises over the constitutionality of statutes that mandate warrantless searches in furtherance of government regulation. United States $v$ Biswell, 406 US 311, 311-12 (1972) (upholding statute permitting warrantless searches of gun dealers); Camara, 387 US at 526 (holding statute that allowed warrantless inspections for code violations to be unconstitutional).

${ }^{87}$ Initially the justification for the exception rested on a theory of "implied consent." Participation in an industry with a long history of regulation implies that the individual expects regulation as a part of the business. Colonnade Catering Corp $v$ United States, 397 US 72, 75 (1970) (discussing historical basis for inspections in the liquor industry). However, the history of regulation has proven less important than the presence of prevalent regulation in a particular industry as a justification for the exception. See Biswell, 406 US at 316 (Prevalence and regularity of regulation are crucial to determining whether exception should exist.); Donovan, 452 US 594 at 600-05 (Exception recognized in light of extensive regulation and an adequate procedural substitute for a warrant.).

389 US 347,360 (1967).

$\approx$ Id. 
ception rests on the ground that certain specific industries are so closely regulated that their members lack a reasonable expectation of privacy, however, courts have denied the exception in situations where a statute authorizes warrantless searches that are not tailored to a particular closely regulated industry. ${ }^{90}$

In its most recent formulation, New York $v$ Burger, ${ }^{91}$ the Supreme Court limited the exception to situations where there is no objective expectation of privacy. As a threshold requirement under Burger, the industry upon which a warrantless search regime is imposed must be closely regulated. ${ }^{92}$ In addition, for a search to be reasonable, the government request must meet three criteria: the search must further a substantial government interest; the search must be necessary to further this interest; and the regulation scheme must provide "a constitutionally adequate substitute for a warrant. ${ }^{193}$ Recently, courts have applied the exception to an increasing variety of industries. ${ }^{94}$

\section{The National Security Exception}

In his concurring opinion in Katz, Justice White raised the possibility that national security may warrant a Fourth Amendment exception..$^{95}$ Under the national security exception, courts would presume a search reasonable if the interest in national security is sufficiently strong to justify the intrusiveness of a search. The Supreme Court has never recognized a national security exception to the Fourth Amendment, but lower courts have

${ }^{90}$ In Marshall $v$ Barlow's, Inc, 436 US 307, 321 (1978), the Supreme Court found a portion of the Occupational Safety and Health Act of 1970 ("OSHA") unconstitutional because it allowed warrantless searches into any workplace. The Court held that statutes not tailored to a particular industry with a history of extensive regulation are unconstitutional to the extent that they allow warrantless searches. Id (holding that reasonableness "will depend upon the specific enforcement needs and privacy guarantees of each statute").

21 482 US 691, 700 (1987).

${ }^{22}$ Id. Close regulation depends on the "pervasiveness and regularity" of regulationthe test outlined in Donovan, 452 US at 606. See also Burger, 482 US at 701, citing Donovan, 452 US at $600,606$.

${ }^{83}$ Burger, 482 US at 702. The "constitutionally adequate substitute" test has two requirements that mimic the role of the warrant: that the individual is aware that the search is "made pursuant to the law and has a properly defined scope," and that the discretion of the officers is limited. Id at 702.

${ }^{2}$ For an exposition of the various industries that have been labeled "closely regulated," see John Wesley Hall, Jr, 2 Search and Seizure § 34:7-19 at 392-401 (Clark, Boardman \& Callaghan 2d ed 1993).

${ }^{25}$ "We should not require the warrant procedure ... . if the President ... [or] the Attorney General [ ] has considered the requirements of national security and authorized [ ] surveillance as reasonable." 389 US at 364 (White concurring). 
occasionally allowed a narrow exception that has generated considerable controversy. ${ }^{96}$

Proponents of the national security exception claim that the exception has deep historical roots. ${ }^{97}$ Because the Constitution grants national security power exclusively to the executive and legislative branches, courts have held that national security issues are "political questions," which are not justiciable. ${ }^{98} \mathrm{Al}-$ though the national security exception and the political question doctrine have aspects in common, ${ }^{99}$ their underlying principles are not the same. The political question doctrine is fundamentally a doctrine of judicial deference: The judiciary should refuse to decide questions, such as those involving national security, that are fundamentally political in nature. ${ }^{100}$ The national security exception, on the other hand, can be viewed as a reasonableness exception to the warrant requirement, derived from Katz rather than from the political question doctrine.

The national security exception is narrowly tailored. For example, the government has invoked its national security interests as a means to acquire foreign intelligence without a warrant. ${ }^{101}$ In these situations, courts have permitted warrantless wiretapping because of the need for secrecy and because of an unwillingness to limit executive branch action. However, courts have required a tight nexus between the person wiretapped and a foreign state. ${ }^{102}$ 1980).

${ }^{*}$ See, for example, United States v Truong Dinh Hung, 629 F2d 908, 911 (4th Cir

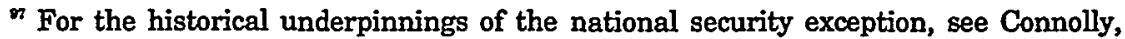
Note, 24 Stan J Intl L at 211-15 (cited in note 13). National security authority has traditionally been interpreted as a part of the executive power vested in the President. See US Const, Art II, $\$ 1$, cl 1. See also Jody S. Fink, The Foreign Policy Role of the President: Origins and Limitations, 11 Hofstra L Rev 773, 790-93 (1983) (discussing the President's implied powers).

* See, for example, Zweibon v Mitchell, 516 F2d 594, 623-24 (DC Cir 1975).

${ }^{\infty}$ One court has upheld the national security exception on the grounds of the political nature of the activity. See Truong Dinh Hung, 629 F2d at 914-15 (permitting warrantless wiretap due to the compelling needs of the executive branch, noting that the executive is constitutionally designated as the "pre-eminent authority in foreign affairs"). See also United States v Erlichman, 546 F2d 910, 928 (DC Cir 1976) (noting that in order to "fix accountability and centralize responsibility," a national security exception to the warrant requirement would mandate personal authorization by the President or the Attorney General).

${ }^{100}$ See Baker $v$ Carr, 369 US 186, 208-37 (1962) (discussing justifications for the political question doctrine). See generally Jonathan I. Charney, Judicial Deference in Foreign Relations, in Louis Henkin, Michael J. Glennon, and William D. Rogers, eds, Foreign Affairs and the U.S. Constitution 98 (Transnational 1990) (analyzing various arguments for judicial deference on international questions, but concluding that courts should not abstain in most cases).

${ }^{101}$ Truong Dinh Hung, 629 F2d at 914-15.

${ }^{102}$ See id at 915 (applying exception "only when the object of the search or the surveillance is a foreign power, its agent or collaborators"); Zweibon, $516 \mathrm{~F} 2 \mathrm{~d}$ at 652-53 (The in- 
Indeed, in United States $v$ United States District Court (Keith), ${ }^{103}$ the Supreme Court stated that a national security exception was not reasonable without a nexus to a foreign state because "Fourth Amendment freedoms cannot properly be guaranteed if domestic security surveillances may be conducted solely within the discretion of the Executive branch." 104

The national security exception to the Fourth Amendment has rarely been applied. Moreover, its boundaries are extremely narrow. However, no court has been presented with an opportunity to explore the contours of a national security exception in a non-espionage situation, such as that presented by the CWC.

\section{E. The Validity of CWC Inspections}

When the CWC verification procedures are scrutinized under Fourth Amendment standards, problems become apparent immediately. Without an obligation to obtain a warrant, searches conducted in the United States by the OPCW may be constitutionally invalid. In order to analyze potential Fourth Amendment problems, this Part will next look at the two major types of verification procedures-regular on-site inspections and challenge inspections-to determine whether and to what extent the verification regime can avoid Fourth Amendment concerns.

\section{Regular on-site inspections.}

On-site inspections should avoid any Fourth Amendment problems. The. National Authority will usually have sufficient time to obtain a warrant after the OPCW provides notification of an inspection. Even if the National Authority cannot (or does not wish to) obtain a warrant in time, many of the inspected facilities are extensively regulated, raising the possibility of a closely regulated industry exception.

a) Schedule 1 and Schedule 2 facilities. Facilities that produce Schedule 1 or Schedule 2 chemicals share four major similarities. First, there are extremely few of them within the United States. ${ }^{105}$ Second, these facilities produce relatively small amounts of controlled chemicals. ${ }^{106}$ Third, the facilities are subject

dividual or organization subjected to a wiretap must be a direct agent of a foreign power to trigger the national security exception.).

${ }^{103} 407$ US 297 (1972). The Keith decision focused solely on the use of the national security exception against domestic problems, where the individuals searched lacked any foreign involvement. Id at 320.

${ }^{104}$ Id at 316-17. 
to tight regulation. ${ }^{107}$ Fourth; and most importantly, facilities that produce these chemicals are required to reach facility agreements with the OPCW that outline the scope of a potential search. ${ }^{108}$

Searches of facilities that produce Schedule 1 or Schedule 2 chemicals will not raise constitutional problems. ${ }^{109}$ Many facilities will allow warrantless inspections to be conducted pursuant to facility agreements, which are likely to grant consent to any search made of the premises. ${ }^{110}$ Even without such an agreement, warrantless searches would fit under the closely regulated industries exception to the Fourth Amendment. The facilities in question form a limited part of a single industry and are subject to comprehensive regulation under the CWC disclosure regime. These elements suggest that Schedule 1 and Schedule 2 producing facilities constitute a closely regulated industry. Moreover, the elements of the Burger test are met: ${ }^{111}$ the enforcement of the CWC is a significant government interest, inspections are necessary to ensure compliance, and the facility agreements form an "adequate constitutional substitute" for a warrant.

b) Schedule 3 and Other facilities. Facilities that produce Schedule 3 chemicals or Other identified chemicals will be subject to inspection obligations similar to those required of Schedule 1

${ }^{10}$ Authorization only exists for one Schedule 1 facility within each State Party. See note 37. Presently, there are "[0]nly a few" facilities in the United States that produce Schedule 1 chemicals and two or three hundred facilities that produce those covered by Schedule 2. OTA, Chemical Weapons Convention at 15 (cited in note 46).

${ }^{100}$ Schedule 1 facilities are limited to producing one tonne of Schedule 1 chemicals per year. See note 37 . Schedule 2 chemicals are, by definition, chemicals that are produced only in limited quantities. The limitation of individual Schedule 2 chemicals is outlined at CWC, Verification Annex, Part VII, II 3, S Treaty Doc 103-21 at 409.

${ }^{107}$ Extensive data declarations are required for all limited chemicals. In addition, Schedule 1 facilities are subject to continuous monitoring. Id at Verification Annex, Part VI, T 22, S Treaty Doc 103-21 at 407.

${ }^{100}$ Id at Verification Annex, Part VI, II 25, S Treaty Doc 103-21 at 407 (Schedule 1 facilities); id at Verification Annex, Part VI, II 24, S Treaty Doc 103-21 at 414 (Schedule 2 facilities). Though the CWC mandates that each facility reach an agreement with the OPCW, the pending United States implementation legislation provides that the agreements cannot require that a person waive her constitutional rights. Revised Implementation Bill § 102, 143 Cong Rec at S 5071 (prohibiting waivers of constitutional rights "as a condition for entering into a contract with the United States or as a condition for receiving any benefit from the United States" for purposes of furthering the CWC).

${ }^{200}$ While this Part focuses on regular, on-site inspections, challenge inspections are also unlikely to prove constitutionally suspect due to the minimal expectations of privacy at Schedule 1 and Schedule 2 facilities.

${ }^{110}$ Because parties can waive their constitutional rights by contract, Zap $v$ United States, 328 US 624, 628 (1946), consensual searches do not violate the Fourth Amendment.

"See notes 91-94 and accompanying text. 
and Schedule 2 facilities. ${ }^{112}$ These facilities, however, are not required to sign facility agreements. Furthermore, unlike Schedule 1 or Schedule 2 producing facilities, these facilities are large-scale producers of chemicals; production of Schedule 3 chemicals is not limited. ${ }^{113}$ Because it is estimated that there will be at least one thousand declared Schedule 3 facilities and ten thousand Other facilities within the United States, ${ }^{114}$ inspections of these facilities will occur much more randomly and sporadically than at Schedule 1 or Schedule 2 facilities.

These differences suggest that the inspections of Schedule 3 and other facilities will not meet the closely regulated industry exception, since the "industry" regulated is tricky to define ${ }^{115}$ and searches will be infrequently performed. ${ }^{116}$

Realistically, though, on-site inspections of facilities that produce Schedule 3 and Other chemicals will not raise Fourth Amendment problems. The United States National Authority must be notified at least $\mathbf{1 2 0}$ hours (or five days) before the proposed inspection. ${ }^{117}$ This requirement will provide sufficient time for the National Authority to advise the facility that is to be inspected, to seek its consent, and, if consent is denied, to acquire an administrative search warrant. ${ }^{118}$

\section{Challenge inspections.}

Challenge inspections raise more serious Fourth Amendment concerns, both theoretically and practically. First, a warrant requirement will be most onerous for challenge inspections because only twelve hours notice is required before an inspection may be-

\footnotetext{
${ }^{112}$ See Part I.A.

${ }^{113}$ CWC, Chemical Annex, Guidelines for Schedule 3 chemicals, S Treaty Doc 103-21 at 327.

${ }^{114}$ See OTA, Chemical Weapons Convention at 15 (cited in note 46).

${ }^{11}$ The CWC defines an Other facility as any facility that produces non-explosive hydrocarbons. This includes all facilities that produce organic chemicals other than petroleum products. CWC, Verification Annex, Part IX, II 1-2, S Treaty Doc 103-21 at 423 . In theory, this definition also includes facilities outside the chemical industry, such as plastics producers.

${ }^{118}$ To determine whether the inspections of Schedule 3 and Other facilities are searches, courts must apply the Katz reasonableness formulation. It is obviously difficult to determine whether a subjective expectation of privacy will exist in any particular situation, or, if regular inspections of these facilities occur randomly once every twenty years, it would be objectively reasonable to be surprised when searches actually occur.

${ }^{117} \mathrm{CWC}$, Verification Annex, Part VIII, II 25, S Treaty 103-21 at 421 (Schedule 3 facilities); id at Verification Annex, Part IX, II 21, S Treaty Doc 103-21 at 426 (Other facilities).

${ }^{118}$ Administrative search warrants will not be difficult to obtain. The government will probably only be required to present an affidavit stating that the CWC is in force and that the search is being made pursuant to the Convention. Revised Implementation Bill § 305(b), 143 Cong Rec at S 5075.
} 
gin and because the inspection process must begin within twelve hours of arrival at the point of entry. ${ }^{119}$ On the other hand, a warrant requirement seems particularly justified in this context, given that challenge inspections are the most intrusive inspections authorized by the CWC. These inspections may be performed on any facility without limitation to a particular industry.

The challenge inspection procedure does not guarantee that a warrant will be obtained, so the National Authority usually will have less than twelve hours to persuade a magistrate to issue a search warrant. ${ }^{120}$ Unlike regular inspections, the National Authority probably will have to obtain a criminal search warrant $^{121}$ rather than an administrative warrant. This raises serious concerns because less evidence will likely be required to receive permission from the Executive Council than would be required to constitute probable cause-a requirement for a criminal search warrant. ${ }^{122}$ In cases where a challenge inspection is not based on sufficient evidence to demonstrate probable cause, courts will be left in a quandary. ${ }^{123}$

${ }^{119} \mathrm{~A}$ loophole does exist that allows inspected states to delay an inspection of the actual facility for up to 108 hours without violating the CWC. CWC, Verification Annex, Part X, I 39, $S$ Treaty Doc 103-21 at 435. However, the facility perimeter must still be secured within twelve hours of arrival, id at Verification Annex, Part X, II 23, S Treaty Doc 103-21 at 432 , and, for reciprocity reasons, the United States should not depend upon this loophole.

${ }^{120}$ It is true that in many situations warrants can be obtained quite quickly, because the law enforcement official requesting a warrant is likely to know the judge, who will be well-acquainted with the legal requirements of reasonableness and the procedural routine. However, in the case of a CWC warrant request, the National Authority would have only twelve hours to ask the inspected facility for consent, prepare the necessary evidence, travel to the appropriate location, and prepare a brief for a judge who is probably unfamiliar with the challenge inspection process.

${ }^{121}$ See Ratification Resolution $\$ 2(28)(A)(i), 143$ Cong Rec at S 3657. The need for a criminal warrant is based upon the potential criminal liability of the noncomplying State and upon the use of the challenge inspection as a deterrence device.

${ }^{122}$ A request for a challenge inspection is denied only if it is proven "frivolous" or in bad faith. CWC, Art IX, I 17, S Treaty Doc 103-21 at 312. Veto of a request for a challenge inspection requires rejection by three-quarters of the executive council. Id. The requirements necessary to prove probable cause are outlined in the implementation legislation. Revised Implementation Bill § 305(b)(4), 143 Cong Rec at S 5075.

${ }^{123}$ Under the CWC, the constitutionally worst-case scenario is when a State Party requests a challenge inspection but lacks sufficient evidence to justify probable cause. One solution to this problem might be to deny the warrant and inspection, subject to Part $\mathrm{X}$, I 41 of the Verification Annex. However, courts might choose to defer to the President's foreign relations power and authorize a warrant on these grounds. This solution is discussed in Part III.C. 


\section{POTENTIAL SOLUTIONS}

In its effort to verify compliance, the scope of the CWC's challenge inspection procedure strains the requirements of the Fourth Amendment. To avoid Fourth Amendment problems, the search must be reasonable, as determined by the issuance of a warrant or by meeting one of the established exceptions to the Fourth Amendment. The challenge inspection, however, does not fit within any previously constructed Fourth Amendment exception, and the CWC's time constraints will cause some challenge inspections to occur without a warrant. Therefore, the procedure must be reconciled with the Fourth Amendment, or else the United States may fall out of compliance with the treaty. ${ }^{124}$

\section{A. A Mandatory Warrant Requirement?}

Intending to provide to its constituents maximum protection against unreasonable searches or seizures, ${ }^{125}$ the Senate required, as a condition to the ratification of the CWC, that the President certify:

that- (i) for any challenge inspection conducted on the territory of the United States . . . the United States National Authority will first obtain a criminal search warrant . . . (ii) for any routine inspection of a declared facility . . . conducted on the territory of the United States.... [the] National Authority first will obtain an administrative search warrant. ${ }^{126}$

The enactment of implementation legislation, which, as currently formulated, requires mandatory warrants for nonconsensual searches and gives detailed specifications for probable cause requirements, ${ }^{127}$ will enforce this solution. If constitutional these provisions may reduce the strain on civil liberties caused by the challenge inspection.

Article XXII of the CWC declares that the Articles of the CWC are not subject to reservation. ${ }^{128}$ Yet the Senate conditioned

${ }^{22}$ Failure to comply with the treaty can lead to economic sanctions, negative publicity, and, most importantly, demands for reciprocity from other States Parties, destroying the effectiveness of the CWC. CWC, Art XII, S Treaty Doc 103-21 at 318 (empowering the Conference to take action against noncomplying State Parties).

${ }^{125}$ Ratification Resolution \& 2(28)(A), 143 Cong Rec at S 3657.

${ }^{203} \mathrm{Id}$.

${ }^{127}$ Revised Implementation Bill § 305(b), 143 Cong Rec at S 5075.

${ }^{120}$ CWC, Art XXII, S Treaty Doc 103-21 at 323 ("The Annexes at this Convention shall not be subject to reservations incompatible with its object and purposes."). Condition 28 may be a reservation made to the Annex on Verification rather than a reservation to the Articles themselves. The reservation would conform to the object and purpose of the con- 
ratification on its express right to make qualifications to the treaty. ${ }^{129}$ It based its authority on the Treaty Clause of the Constitution: "[The President] shall have the Power, by and with the Advice and Consent of the Senate, to make Treaties, provided two-thirds of the Senators present concur." ${ }^{\text {"130 }}$ The ability of the Senate to ratify a treaty subject to qualification has never been questioned. ${ }^{131}$ Traditionally the President has possessed the sole authority to negotiate treaties. ${ }^{132}$ Here, it might seem that Congress changed the treaty so much as to actually amend the treaty and therefore encroach on executive authority. If the Senate's power to "advise and consent" is construed narrowly, as it traditionally has been, ${ }^{133}$ the Senate may not have been empowered to amend the CWC, and, therefore, any reservations placed on the CWC may be void. ${ }^{134}$

The Senate did not actually amend the CWC, however. It ratified the CWC subject to twenty-eight "conditions." ${ }^{135} \mathrm{~A}$ "condi-

vention, which already provides exceptions to conform with constitutional requirements. See id at Verification Annex, Part X, II 41, S Treaty Doc 103-21 at 435. However, many of the conditions attached by Congress attack the Articles of the CWC, which may render the entire ratification package invalid as a violation of Article XXII, because no severability clause was included. See, for example, Ratification Resolution $\S 2(1), 143$ Cong Rec at S 3651 (requiring the President to certify that reservations are permitted not withstanding Article XXII).

${ }^{120}$ Ratification Resolution, § 2(1), (17), 143 Cong Rec at S 3651, S 3656.

${ }^{130}$ US Const, Art II, $\S 2, \mathrm{cl} 2$.

${ }^{121}$ In fact, 195 treaties, constituting approximately 15 percent of all treaties ratified, have been ratified subject to some qualification. See Kevin C. Kennedy, Conditional Approval of Treaties By the U.S. Senate, 19 Loyola LA Intl \& Comp L J 89, 91 (1996).

${ }^{132}$ This unqualified negotiating power, initially declared in United States $v$ CurtissWright Export Corp, 299 US 304, 319 (1936), has generated substantial commentary. For contrasting opinions of the President's exclusive authority, compare Louis Fisher, Congressional Participation in the Treaty Process, $137 \mathrm{U} \mathrm{Pa} L \mathrm{Rev} 1511,1512-19$ (1989) (analyzing both the historical basis for presidential negotiating power and the "sole organ" theory), and Alan C. Swan, The Constitutional Power to Terminate Treaties: Who, When, and Why, 6 Yale Stud World Pub Ord 159, 198-99 (1979) (arguing that the rule in CurtissWright improperly limits congressional power), with Michael J. Glennon, The Senate Role in Treaty Ratification, 77 Am J Intl L 257, 276 (1983), and David J. Bederman, Revivalist Canons and Treaty Interpretation, 41 UCLA L Rev 953, 961 (1994) (stating that the executive is generally considered to have absolute power to negotiate treaties).

${ }^{13}$ Substantial, but not determinative, evidence suggests that the Framers of the Constitution may have intended substantial congressional involvement in the treatymaking process. See Fisher, $137 \mathrm{U}$ Pa L Rev at 1512-15.

${ }^{13}$ There is no case law available to determine the proper scope of Congress's authority to place conditions on treaties that are negotiated with no allowance for reservations. The Treaty Clause of the Constitution may alternatively be interpreted in ways that either restrict or empower the Senate. See note 132. While the determination of this issue will affect the interpretation of the CWC, this Comment assumes that warrantless inspections will occur despite their illegality, resulting in the same problem for tribunals.

${ }^{138}$ Congress has used four types of qualifications to alter treaties: reservations, conditions, declarations, and interpretations. Reservations are the only qualification used by Congress that actually "purports to change the legal effect of the treaty upon the United 
tion" does not change the effect of treaty obligations on the United States. ${ }^{136}$ Traditional conditions merely create additional requirements that the United States must meet, some of which may conflict with the CWC. Therefore, to the extent that a conflict exists between the CWC and the Senate's conditions, the law will be unsettled.

The Supremacy Clause of the Constitution expressly includes treaties as part of "the supreme Law of the Land." ${ }^{\text {"137 }}$ It is unclear whether unnegotiated conditions appended to a treaty should be "the supreme Law." If conditions added by the Senate are not treated as equal to the text of the treaty, the National Authority must concern itself primarily with its CWC obligations, attempting to obtain warrants whenever possible. In this scenario, challenge inspections may occur without a warrant.

If the conditions are treated as a part of the body of the ratified treaty, problems may still occur. The United States National Authority must meet both the requirements of the CWC and of the implementation legislation. The simple solution proposed by Congress actually creates two new constitutional problems.

First, the warrant requirement may prove counterproductive, because the "neutral and detached magistrate" who is to make warrant decisions may not be neutral. ${ }^{138}$ In a domestic context, a magistrate may plausibly claim neutrality, because she is uninvolved in the execution of an investigation. Because the CWC is the law, a judge may be unwilling to breach the government's treaty obligations because of constitutional concerns that the judiciary may not be empowered to invalidate a treaty. ${ }^{139}$ It is possible that this magistrate will feel more comfortable granting a warrant lacking sufficient evidence than she would breaching a treaty to which the United States is a party. ${ }^{140}$ Thus, the neutral deliberation promised by the warrant requirement appears illu-

States." Bederman, 41 UCLA L Rev at 958 (cited in note 132). Declarations and interpretations merely clarify legislative interpretations of treaty provisions. Id.

${ }^{138}$ Power Authority of New York v Federal Power Commission, 247 F2d 538, 541-42 (DC Cir), vacated as moot, 355 US 64 (1957). It is unclear whether the Senate chose to declare its twenty-eight conditions to be "conditions" with full understanding of the interpretive meaning of this phrase.

${ }^{132}$ US Const, Art VI, cl 2.

${ }^{138}$ Johnson v United States, 333 US 10, 14 (1948).

${ }^{139}$ See Goldwater $v$ Carter, 444 US 996, 996 (1979).

${ }^{1 *}$ This circumstance offers the most plausible explanation for the inclusion of the constitutionality exception to the challenge inspection procedure, suggesting that judges will, in fact, have the power to deny warrants. See CWC, Verification Annex, Part X, II 41, S Treaty Doc 103-21 at 435. However, the crucial factor here is not whether a judge has the ability to issue a warrant, but whether her neutrality may be plausibly be questioned. 
sory; the warrant issued might not meet Fourth Amendment standards, requiring alternative proof of reasonableness.

Second, parts of the implementation legislation designed to facilitate the warrant process may be unconstitutional. ${ }^{141}$ The proposed legislation sets out the requirements necessary to prove probable cause. This legislation may require courts to adhere to a congressional interpretation of the Constitution, which is problematic because such interpretational power rests primarily with the courts. ${ }^{142}$

Both of these constitutional difficulties compromise the congressional solution to the challenge inspection problem. The Senate conditions are unlikely to assuage the Fourth Amendment concerns under any scenario, which prompts the question of whether there is an alternative solution to the Fourth Amendment problems created by the CWC. Three potential solutions will be considered below.

\section{B. Extending the Closely Regulated Industry Exception}

One possible alternative that may alleviate the Fourth Amendment concerns would be to extend the closely regulated industry exception. ${ }^{143}$ This alternative seems plausible because the majority of challenge inspections will occur in facilities that already produce restricted chemicals, thus possessing diminished privacy expectations. However, this solution is unacceptable for two reasons.

First, the challenge inspection procedure has been interpreted by the Senate in its Implementation Bill as a criminal search, while courts only have applied the closely regulated industry exception to administrative searches. The doctrine was designed to accommodate the diminished privacy needs of an administrative search; to expand the doctrine to a context where

\footnotetext{
${ }^{141}$ Because the Revised Implementation Bill has not been enacted, any discussion of its constitutionality is necessarily speculative. See note 58.

${ }^{142}$ See Marbury $v$ Madison, 5 US 137, 177 (1803) ("II]f a law be in opposition to the constitution ... the court must determine which of these conflicting rules governs the case. This is the very essence of judicial duty."); Cooper $v$ Aaron, 358 US 1, 18 (1958) ("[T]he federal judiciary is supreme in the exposition of the law of the Constitution."); City of Boerne $v$ Flores, $117 \mathrm{~S}$ Ct 2157, 2164 (1997) (Congress has "the power to enforce, not the power to determine what constitutes a constitutional violation.").

${ }^{143}$ See Gray, Note, 94 Colum L Rev at 638 (cited in note 12) (arguing that such an expansion of the exception will provide an optimal solution to the problem of routine inspections). The author admits that challenge inspections of undeclared facilities would require a warrant, id at 632-33, which runs counter to many of the statements that the note makes regarding the importance of reciprocity to an adequately functioning CWC. Id at 628.
} 
searches are designed to uncover criminal activity destroys the intent of the exception because criminal searches warrant higher protection.

Second, the exception has only been allowed when the authorizing statute has been tailored to a particular, wellregulatếd industry. By contrast, challenge inspections may be performed in any workplace or, conceivably, in a private residence. ${ }^{144}$ The closely regulated industry exception exists because certain industries that are pervasively regulated cannot maintain an objectively reasonable expectation of privacy. By expanding the exception to cover challenge inspections, the implication is that participation in any industry in which chemicals are used or manufactured puts an individual on notice for potential criminal searches for CWC violations. This implication treads perilously close to retracting Fourth Amendment protection from businesses.

\section{Judicial Deference: The Political Question Doctrine}

The Constitution delegates broad powers concerning foreign relations to the executive. ${ }^{145}$ Some commentators have suggested that, in light of the need for uniformity in foreign policy, the judiciary should refrain from analyzing the constitutionality of procedures required by a treaty negotiated by the executive. ${ }^{146}$ While the judiciary generally grants great deference to executive actions in foreign policy matters, ${ }^{147}$ this solution will prove unacceptable for the present circumstances.

Executive authority over foreign relations is limited by the requirements of the Constitution. ${ }^{148}$ The executive has no authority to negotiate a treaty that infringes upon rights protected by the Constitution. Under Reid $v$ Covert, ${ }^{149}$ where the Supreme

${ }^{14}$ The latter possibility is slight given the definition of a chemical weapons-producing facility, which sets the production level that proves noncompliance with the CWC at one tonne. CWC, Art II, II 8, S Treaty Doc 103-21 at 283-84.

${ }^{145}$ See note 132 .

${ }^{146}$ Under such a system, the judiciary would decline on jurisdictional grounds to hear all suits brought by victims of warrantless searches. A hypothetical situation of this type is presented in Tanzman, 13 Yale $\mathrm{J}$ Intl $\mathrm{L}$ at 38-41 (cited in note 14).

${ }^{147}$ Consider the deference given to the executive decision to wiretap for foreign intelligence purposes, discussed in Part II.D.

${ }^{14}$ The position that a treaty can never authorize something forbidden by the Constitution was first developed in De Geofroy $v$ Riggs, 133 US 258, 267 (1890). The current formulation of this belief is expressed in Reid v Covert, 354 US 1, 16 (1957) ("[N]o agreement with a foreign nation can confer power on the Congress, or on any other branch of Government, which is free from the restraints of the Constitution.").

${ }^{149} 354$ US 1, 16-17 (1957). The judiciary is empowered to interpret treaties, because treaties are a part of the "supreme Law of the Land," US Const Art VI, cl 2. See Kolourat $v$ 
Court invalidated an executive agreement on the grounds that the executive could not use the treaty power to supersede his constitutional authority, courts scrutinize the actions of the executive branch to determine that it has not exceeded its constitutional limitations. To the extent that the challenge inspection violates Fourth Amendment rights, judicial deference becomes an abdication of a constitutionally mandated responsibility. Because it fails to question whether executive power has outstripped its mandate, judicial deference is too blunt a tool to use in the delicate process of treaty compliance.

\section{A National Security Exception}

In order to protect the Fourth Amendment rights of the citizenry while adhering to treaty obligations, the judiciary must review executive actions. In particular, courts must determine whether an inspection conducted without a warrant is independently reasonable. The interests of national security provide a basis on which to make this determination. One commentator has recently suggested that the unmodified national security reasonableness test may save the constitutionality of the challenge inspection. ${ }^{150}$ She contends that the interests of national security, as defined by the executive, "would be sufficient to support a finding that the government's interest outweighs the individual's privacy interests. ${ }^{\$ 151}$ Thus, in her opinion, the national security exception, as currently constructed, would grant challenge inspections per se reasonableness. ${ }^{152}$

Two problems, however, limit the usefulness of the national security exception as it is currently formulated. First, existing case law demonstrates an absolute unwillingness to apply a national security exception domestically. ${ }^{153}$ If applied domestically, the executive could invoke the national security exception in any situation where the government feared that the activities of its citizens posed a direct threat to the government.

Oregon, 366 US 187, 194 (1961) (" $[C]$ ourts interpret treaties for themselves . ...").

${ }^{150}$ See Bing-Zaremba, Comment, 11 Temple Intl \& Comp L J at 75-76 (cited in note 13).

${ }^{151} \mathrm{Id}$ at 75 .

${ }^{152}$ Bing-Zaremba does not identify any normative changes that must be made to the national security exception in order for it to protect challenge inspections in the domestic context, nor does she adequately explain the relationship between executive pronouncements of national security and the Fourth Amendment national security test. For a discussion of civil liberties problems that may result from using the national security exception in this way, see Part IV.A.

${ }^{163}$ See Part II.D. 
Second, "national security" is generally viewed as the Pandora's box of totalitarianism. Once courts develop a national security exception for the Fourth Amendment, critics fear that courts will find the exception increasingly difficult to limit, given the large number of activities that the government may characterize as involving national security. ${ }^{154}$ Unlike the other reasonableness exceptions, which have been developed with particularity by courts, the executive has traditionally maintained the power to determine whether something is a matter of national security. An unmodified national security exception would fail to protect constitutional civil liberties sufficiently.

However, modifying the national security exception by including a requirement that the national security search be reasonable can produce major benefits. Developing such an exception will create a rational justification for judicial oversight of the treatymaking power of other branches. Previously, courts have allowed the President to invoke national security by relying on the political question doctrine, which, in this context, begs the question of whether the executive decision legally can be made. The proposed exception would allow some judicial deference while sustaining the judiciary's ultimate power of oversight and would give judges a way to defer temporarily to the United States's treaty obligations while allowing the judiciary to retain the ability to make a reasonableness determination.

\section{EXPLORING THE NATIONAL SECURITY EXCEPTION}

The United States has bound itself both to the CWC and to Congress's own supplementary conditions. Though the National Authority will obtain warrants whenever possible, circumstances will arise when it will not be able to do so. Of the aforementioned solutions, modifying the national security exception provides the only alternative that can protect both the constitutional rights of parties inspected and the governmental obligation to uphold the treaty.

\footnotetext{
${ }^{134}$ See Gray, Note, 94 Colum L Rev at 635-38 (cited in note 12) (providing a vehement argument against broadening the national security exception); David B. Kopel and Joseph Olson, Preventing a Reign of Terror: Civil Liberties Implications of Terrorism Legislation, 21 Okla City U L Rev 247, 331-33 (1996) (equating the use of warrantless national searches with the British Star Chamber, which violated common law search rules to terrorize dissident citizens); David S. Eggert, Note, Executive Order 12,333: An Assessment of the Validity of Warrantless National Security Searches, 1983 Duke L J 611, 629-35 (arguing that no use of the national security exception should be constitutional).
} 


\section{A. Should a National Security Exception Exist?}

Critics base their attacks on the national security exception on two arguments, one ideological and one pragmatic. ${ }^{155}$ Some critics are fearful of the national security exception because they fear the destruction of rights; any exception to the warrant requirement, which may label an entire class of inspections reasonable, threatens Fourth Amendment rights. In this context, no national security interest is strong enough to overcome the constitutional protection of privacy afforded by the Fourth Amendment. ${ }^{156}$ One critic finds the national security exception particularly disturbing because the exception is extremely hard to limit. ${ }^{157} \mathrm{Be}$ cause the executive can determine what constitutes national security, critics believe that the judiciary will never be able to control the exception, inevitably leading to the destruction of Fourth Amendment protection.

\section{Loss of rights.}

The use of a national security exception must ultimately be justified as a balancing test. ${ }^{158}$ The recent history of Fourth Amendment jurisprudence supports the claim that civil rights may be limited in the face of an overarching policy concern. ${ }^{159}$ The interests involved in national security clearly demand a similar balancing test, under which the legitimate preservation of sovereignty must be weighed against the importance of individual rights. The legislature has recently decided that civil rights are outweighed by national security concerns in the context of alien deportation: The Antiterrorism and Effective Death Penalty Act of 1996 allows the United States government to deport aliens when a suspicion of terrorist activity poses a threat to national

${ }^{156}$ Gray outlines a number of practical problems with the implementation of a domestic national security exception. See Gray, Note, 94 Colum L Rev at 634-38 (cited in note 12). Kopel and Olson outline an ideological argument against the expansion of the exception. See Kopel and Olson, 21 Okla City U L Rev at 329-35 (cited in note 154).

${ }^{13 s}$ See, for example, Gray, Note, 94 Colum L Rev at 640-41 (cited in note 12) (noting that inquiry into reduced privacy expectations necessarily involves case-by-case analysis and is thus "no more than a rule of thumb"); Kopel and Olson, 21 Okla City U L Rev at 329-35 (cited in note 154).

${ }^{157}$ Gray, Note, 94 Colum L Rev at 635 (cited in note 12).

${ }^{15 s}$ The belief that citizens must necessarily balance civil liberties with national security interests is best expressed in Henkin, Foreign Affairs and the Constitution at 255 (cited in note 1) (discussing Fourth Amendment concerns and arms control inspections).

${ }^{15}$ For example, warrantless stop and frisk searches are constitutional when made on reasonable suspicion because such searches are necessary to enforce certain criminal statutes, despite an individual's obvious expectation of privacy. See Terry, 392 US at 27 (allowing search for weapons if officer reasonably believes that suspect is armed and dangerous); Sibron $v$ New York, 392 US 40, 66 (1968) (fleeing suspects). 
security. ${ }^{160}$ In addition, the Supreme Court found a similar balance in United States $v$ Verdugo-Urquidez, ${ }^{161}$ holding that extradition of an alien to the United States does not provide that alien with Fourth Amendment rights. These instances illustrate that the civil rights of individuals can be limited in the face of overarching policy concerns.

\section{Loss of judicial control.}

The argument that the executive will determine what constitutes national security demonstrates the same conflation of the political question doctrine and Fourth Amendment reasonableness that has plagued judicial consideration of the national security exception. The executive clearly has the authority to label certain issues as involving national security. When it is constitutional to do so, courts should adhere to this opinion and should decline to rule on subsequent claims.

The judiciary must remain vigilant in limiting the executive's power to use national security in an unconstitutional manner. The Supreme Court did just that in Keith. ${ }^{162}$ Second, when determining whether a search is reasonable, courts should use their own interpretation of the Fourth Amendment to determine what level of national security interest reasonably merits an exception from the warrant requirement.

Ultimately, the determination of whether to allow a national security exception depends on a measurement of the interests at stake. An interest of national security should make a search objectively reasonable if the interest is sufficiently grave and if the magnitude and probability of injury to the individual is slight. In the context of the CWC, this balance will often weigh in favor of national security for two reasons. First, the destruction of chemical weapons is a true interest of national security; few would argue that the nation's interests are not best served by the universal elimination of these devices. Second, adherence to ratified treaty obligations are a central concern to the nation. If the United States cannot be trusted to adhere to its responsibilities, it will lose international credibility. Thus, if a national security exception can be developed that will minimize the risk of injury to civil liberties, then the exception should be used.

\footnotetext{
${ }^{100}$ Antiterrorism and Effective Death Penalty Act of $1996 \S \S 438,442$, Pub L No 104132,110 Stat 1214, codified at 8 USCA $\$ \S 1105 a, 1252,1252 a, 1326$ (Supp 1997).

${ }^{161} 494$ US 259, 266 (1990).

${ }^{102} 407$ US at 320 (disallowing national security exception for purely domestic concerns). In foreign intelligence cases, the nexus between foreign relations and national security is a tight one; in the CWC context, the nexus is slightly more attenuated.
} 


\section{B. Can a National Security Test Be Developed?}

In order for the national security exception to maintain credibility, courts must limit the cases where "national security" may be invoked. A national security exception should only exist if it seems reasonable that a particular type of search should be conducted without a warrant. To effectively protect civil liberties, an exception must utilize both substantive limitations, to determine whether the claimed interest is really a national security interest at all, and procedural limitations, to determine whether the interest reasonably merits an exception from the warrant requirement.

Substantively, courts must determine whether a certain type of activity is in the interest of national security. The opinion of the executive will, doubtless, play a large role in this determination. In the past, courts have limited the use of national security to cases that involve foreign relations directly, ${ }^{163}$ such as wiretapping cases where the court required a direct nexus to a foreign state. Courts limit the exception for two reasons. First, out of fear that civil liberties may be compromised, courts limited the national security exception to cases where the integrity of the nation was at risk. ${ }^{164}$ Second, courts sought to tailor the exception to its purpose: a national security exception should be allowed only where it was objectively clear that national security, not domestic control, propelled the need for the exception. ${ }^{165}$ In a reformulated national security exception, these goals should be upheld, because they provide a rational limitation for national security. However, as the CWC makes obvious, counter-intelligence is not the only threat to national security. It is also threatened by weapons of mass destruction and by reputational harm for failure to adhere to treaty obligations. Thus, courts may decide to expand the scope of the exception while retaining its essential purpose.

A class of searches may be excepted from the Fourth Amendment warrant requirement if the class meets the following national security test. The threshold determination is whether the search is truly performed for a national security purpose. This determination is made by analyzing the government's interest in light of the two subjective requirements of national security: the interest must relate directly to the integrity of the na-

${ }^{163}$ See Part II.D.

${ }^{16}$ See, for example, Keith, 407 US at 314-15 ("As the Fourth Amendment is not absolute in its terms, our task is to examine and balance the basic values at stake in this case: the duty of Government to protect the domestic security, and the potential danger posed by unreasonable surveillance to individual privacy and free expression.").

${ }^{165} \mathrm{Id}$. 
tion, and the interest must be to protect the nation rather than to suppress a dissident group. If this threshold is met, the security interest must meet two additional requirements, based on the Burger test for the closely regulated industry exception: (a) the solution must be necessary for the interest to function properly, and (b) the solution must provide an adequate constitutional substitute for a warrant. ${ }^{166}$ The purpose of these additional requirements is to limit any desire the judiciary might have to defer to national security broadly.

However, the next Part will analyze the challenge inspection scenario in particular, to determine whether the procedural and substantive limitations fulfill their duty.

\section{Implementing a National Security Exception}

For the national security exception to solve the constitutional problems raised by the CWC challenge inspection, courts must determine that, because of the objective reasonableness of the national security interests involved, a challenge inspection meets the reasonableness requirements of the Fourth Amendment even without a warrant. In order to meet these requirements, the CWC must meet two criteria: it must be a true national security interest; and its challenge inspection process must be objectively reasonable under the modified Burger test.

\section{True national security.}

To prove that it raises concerns of true national interest, courts must determine that noncompliance with the CWC will result in a threat to the integrity of the nation and that the search serves national security, not domestic control. Because the actual search will be conducted by foreign officials who work for an international organization, the CWC clearly meets the second criterion. Two factors weigh in favor of considering compliance with the CWC to be in the interest of national integrity. First, the integrity of the nation depends on its ability to protect its citizens from attack. Chemical weapons pose a true risk to national security because of their use in terrorist acts, as well as in conventional warfare. Noncompliance, or even delayed compliance, would allow "cheating" states the opportunity to restrict United States inspection teams from conducting inspections. Second, noncompliance will hurt the integrity of the nation because it will

${ }^{166}$ While the use of the Burger test is obviously only an example of a possible procedural constraint that may be applied, for simplicity's sake the test will be used as an example in Part IV.C as well. 
weaken the bargaining position of the United States in the international community.

\section{Objective reasonableness.}

The challenge inspection process must also meet the procedural safeguards of a national security exception, as expressed in the modified Burger test. The inspection procedure has already passed the first hurdle, which requires that the searches must further a national security interest. Courts may disagree on the second hurdle, which is whether the inspections are necessary. Some courts may determine that warrantless challenge inspections are not necessary for compliance with the CWC, because the warrant inspections will suffice to catch violators. However, a more pragmatic judge would understand that the purposes of the CWC, and of national security, cannot adequately be met by a warrant requirement. ${ }^{167}$ The third criterion, whether the CWC's challenge inspection procedure provides an adequate substitute for a warrant, should pose no problem. ${ }^{168}$ All challenge inspections are limited by the CWC to minimize intrusiveness. ${ }^{169}$ In addition, participation by the National Authority should ensure that individuals realize that an inspection has been conducted pursuant to federal law.

Ultimately, unless courts determine that it is never necessary for challenge inspections to proceed without a warrant, a national security exception to the Fourth Amendment should allow warrantless challenge inspections to occur, while retaining judicial protection of Fourth Amendment rights.

\section{CONCLUSION}

In order to eliminate chemical weapons, the CWC requires a verification method, the challenge inspection, which may violate the Fourth Amendment. If the United States proves unable to combat the Fourth Amendment problems through conditions added by the Senate to the CWC at the time of ratification, courts must develop an alternative that maintains the effectiveness of the $\mathrm{CWC}$, while retaining judicial oversight of constitutional

${ }^{105}$ This judge would also realize that a warrant is not mandatory for a search to be constitutional, eliminating the usefulness of the CWC constitutionality clause in this situation.

${ }^{108}$ For the requirements of the actual Burger test, see notes 91-95 and accompanying text.

${ }^{100}$ See CWC, Verification Annex, Part II, II 40, S Treaty Doc 103-21 at 115 ("[T]he inspection team shall avoid unnecessarily hampering or delaying the operation of a facility and avoid affecting its safety ...."). 
rights. The exigencies of the situation provide an opportunity to modify the national security exception to the Fourth Amendment, unshackling the exception from its historic ties to the political question doctrine, and systematizing it, so that national security may be used to measure the reasonableness of the CWC and future treaty verification procedures. 